\title{
Três Figuras do Discípulo \\ na Filosofia Antiga
}

\author{
Francis Wblff*
}

\begin{abstract}
Resumo: Este artigo examina três figuras típicas do discípulo na filosofia antiga: o socrático ("fillho ciumento"), o epicurista ("dbente curado, mas psitacista") e o aristotélico ("hemeneuta insatisfeito").
\end{abstract}

Palavras-chave: filosofia antiga - mestre - discípulo - Sócrates - epicurismo - aristotelismo.

Sabe-se que sucesso teve Sócrates junto à juventude ateniense. Sabese também que, por intermédio dele, a filosofia introduziu-se em Atenas, de onde até então fora mantida quase excluída, e como, a partir dele, ali brilhou em numerosas escolas. Sabe-se enfim a resposta que dava Sócrates àqueles que o acusavam de perverter a juventude e introduzir na cidade novos deuses estranhos: discípulos, jamais os tive; jamais fui mestre de quem quer que seja ${ }^{(1)}$. Do mesmo modo, a quem, nunca se sabe, acusasse Gérard Lebrun, ou a quem talvez já o tenha mesmo acusado, visto seu sucesso já antigo junto às jovens gerações, de perverter a juventude brasileira e introduzir na cidade deuses estranhos à tradição nacional, ele poderia responder do mesmo modo que jamais teve discípulos e que não é um mestre. E com 
efeito quem poderia gabar-se de ser discípulo de G. Lebrun? Ele é tido como um mestre, freqüentemente amado, às vezes vilipendiado como um mestre, mas é sem discípulos e sem doutrina. Sem discípulo: ele teve alunos, que são professores, que têm alunos, dos quais alguns serão professores. Que doutrina, portanto, teria ele tentado impor-lhes? Nenhuma. Que mercadoria teria tentado importar e impor à juventude demasiado ingênua? A história da filosofia, quando muito, mas liberada de toda vocação para revelar verdades. "A tradição se desdbbra diante de nós, com seus conceitos manipuláveis e deformáveis ao bel-prazer do operador. Ela nada tem, portanto, a nos dizer... É-nos concedida a liberdade de trabalhar sobre os textos e jogar com seu conteúdo sem que seja preciso muito esforço para ouvir.."(2)

O que nos ensina, então, este trabalho sobre os textos a propósito da figura do mestre na história da filosofia?

Examinar-se-ão três figuras do discípulo na filosofia antiga: o socrático, o epicurista, o aristotélico. Esta escolha é devida a dois tipos de consideração: a importância "dbjetiva" destas três correntes e o caráter típico das figuras do discípulo que engendraram. Sem dúvida é difícil comparar a importância de doutrinas enquanto tais, mas é fácil avaliar por seus efeitos objetivos a importância de uma corrente ou de uma escola de pensamento que descendem de um mesmo mestre. Ora, de Sócrates provêm, diretamente, algumas das filosofias mais marcantes da história (dentre as quais as de Platão) e, indiretamente, quase todas as correntes filosóficas ulteriores. De Epicuro provém uma doutrina que é sem dúvida, de todas as doutrinas filosóficas (ou seja, não religiosas), aquela que se conservou mais tempo intacta (o estoicismo teve uma vida igualmente longa, mas a própria doutrina transformou-se a cada geração) . Enfim, de Aristóteles provém o conjunto de textos profanos mais lido e mais comentado de toda a história desses dois milênios. Ao mesmo tempo, pareceu-me que aí tínhamos três figuras de discípulos, de uma parte perfeitamente distintas (mesmo se existem constantes entre elas) e de outra parte inteiramente típicas, e não somente na história da filosofia, mas talvez típicas de toda relação mestre/discípulo(3). Esgotam estas três figuras todos os tipos possíveis, a ponto de que todos os discípulos reais deveriam, como penso, alinhar-se em última análise numa dessa três figuras? Ou há outras completamente irredutíveis a estas três?
Comecemos por caracterizar de uma maneira ainda geral e esquemática cada uma destas figuras, colocando em evidência o destino do discípulo, o modo de relação que o ligava ao mestre e a contradição que define esse destino e essa relação.

O socrático é o discípulo cujo destino consiste em criar uma doutrina própria apoiando-se sobre a autoridade do nome do mestre e em fixar definitivamente e para todos aquilo que devia pessoalmente ao mestre, mas que o mestre não pôde dizer inteiramente. A relação que o ligava ao mestre é uma relação de amor. Cada discípulo socrático desenvolve por sua conta após a morte do mestre esta relação pessoal que o ligava ao mestre escrevendo e portanto sistematizando aquilo que devia ao mestre; fazendo isso ele se choca com os condiscípulos que fazem o mesmo e, portanto, dizem o contrário. Ele encontra a contradição no outro discípulo. Seu destino é ligado a esta contradição de não poder se dizer legitimamente discípulo do mestre senão com a condição de negar que os outros o sejam.

Em oposição, o epicurista. O epicurista é o discípulo que seu destino condena, ao contrário, a não poder nada acrescentar, nada el iminar à letra já escrita de uma vez por todas pelo mestre e que, portanto, só pode repeti-la. A relação que o ligava ao mestre é a do doente com o médico que o curou. Fazendo isso, é na sua própria posição de discípulo que reencontra a contradição; se ele não pode finalmente ser um bom discípulo senão repetindo o mestre, não pode ser um discípulo senão se fazendo ele mesmo um mestre, ocupando para um outro esta posição de médico que o mestre ocupava para ele. Seu destino é ligado a esta contradição de não poder ser discípulo senão se fazendo mestre.

Entre o epicurista e o socrático, há o aristotélico. O aristotélico é o discípulo cujo destino consiste em esquadrinhar ao infinito aquilo que o mestre pôde querer dizer e não termina por seu comentário de totalizar, de acabar os escritos do mestre. A relação que o ligava ao mestre não é direta, visto que passa pela mediação dos textos deixados pelo mestre; entretanto, esta relação é pensada segundo o modo da relação docente do aluno com o professor. Realizando seu destino, que é explicar, comentar, interpretar o pensamento do mestre, o discípulo se choca também a uma contradição que ainda aqui é o seu motor: mas desta vez ele a reencontra no próprio texto do 
mestre, cujas tensões ou ambigüidade são inultrapassáveis e condenam sua empreitada ao recomeço infinito.

Vejamos isso de mais perto: os socráticos, imãos órfãos dilacerados; o epicurista, doente curado mas psitacista; e o aristotélico, hermeneuta insatisfeito.

\section{O discípulo socrático: o filho ciumento}

A primeira figura do discípulo que nos é oferecida é ao mesmo tempo a mais problemática. Ela é talvez, num outro sentido, a mais emblemática.

Sabe-se que a maior parte das doutrinas filosóficas que nasceram na Antiguidade são consideradas como os diferentes ramos de um mesmo tronco tendo por nome Sócrates. Desde a morte de Sócrates, com efeito, seus antigos ouvintes se puseram a escrever em seu nome segundo um gênero literário, o diálogo socrático - dos quais nos chegaram apenas as obras de Platão e Xenofonte e raríssimos fragmentos dos diálogos de Esquino de Sphettos, dito "o socrático", que escreveu sete, ao que parece, dos de Fedon de Elis ou de Antístenes. Cada qual aí invocava e aí defendia a memória do mestre, pretendendo restituir a letra das conversas de Sócrates com seus interlocutores. Mas ao mesmo tempo, paralelamente a este gesto que fixava a fala do mestre no escrito (um escrito que aliás se avançava mascarado por detrás do arremedo da palavra viva do mestre, o diálogo), cada qual instituía, pela fundação de uma escola, a transmissão do único ensino autêntico e legítimo desta palavra do mestre. Platão funda em Atenas a Academiar Aristipo funda uma escola em Cirena, Fedon funda uma em Elis, Euclides uma outra em Mégara, e Antístenes inspira o movimento dos Cínicos. Cada escola se pretendia bem seguramente a única depositária legítima de um testamento espiritual que o mestre não deixara e é por que uma das funções não negligenciáveis dos diálogos socráticos era oferecer um artifício literário cômodo para as refutações, calúnias e excomunhões diversas que os herdeiros se lançavam mutuamente: cada qual entre eles podia colocar na boca de Sócrates suas próprias posições e nas dos interlocutores que Sócrates refutava as posições de seus rivais socráticos.
A questão clássica é saber como tudo isso é possível. Pois o historiador, talvez nisso mais ingênuo que o psicanalista, espanta-se que fillhos tão dissemelhantes e freqüientemente antagonistas tenham podido se reclamar de um mesmo pai. Como puderam se dizer socráticos ao mesmo título e aparentemente segundo os mesmos direitos o ascetismo de Antístenes e o hedonismo de um Aristipo ${ }^{(4)}$, o logicismo de um Euclides e o "idealismo" de um Platão?

Do mesmo modo que se fala de paradoxo socrático a propósito da filosofia moral de Sócrates, talvez seja permitido falar do paradoxo do socrático a propósito do discípulo de Sócrates. Este paradoxo definirá ao mesmo tempo nossa primeira figura.

Há três maneiras equivalentes de formulá-lo.

O primeiro aspecto do paradoxo do socrático reside apenas no fato de que haja discípulos. Alguns dentre os ouvintes de Sócrates eram considerados seus discípulos ${ }^{(5)}$. Ora, Sócrates, quanto a ele, não reconhece nenhum discípulo e se denega toda mestria ${ }^{(6)}$. Ainda aí os textos são desprovidos de ambigüiidade ${ }^{(7)}$ : Sócrates não vê em nenhum de seus ouvintes ou companheiros de bando um discípulo no sentido verdadeiro do termo. Como portanto ser discípulo daquele que não se quer mestre?

Segundo aspecto do mesmo paradoxo. Ser discípulo, isto implica que se aprenda alguma coisa do mestre e que o mestre tenha algo a ensinar, um certo número de doutrinas consideradas como verdadeiras que o discípulo deve ele mesmo ter por verdadeiras depois de tê-las compreendido, assimilado, retido. Ora, Sócrates vai repetindo que nada sabe, que não tem lição para dar, que nada tem a oferecer senão sua "convivência" (s u nous .a ) ${ }^{(8)}$. Aliás, ele nada escreve, não fixa doutrina alguma que se possa ou deva reter. Como ser um discípulo sem disciplina, o discípulo de um mestre sem ensinamento?

Terceiro aspecto do mesmo paradoxo. Ser discípulo não é somente reconhecer-se um mestre a quem se deve aquilo que se é e um corpo de saber ou de verdades que a ele se deve, mas além disso reconhecer-se em outros e ver neles o produto do mesmo mestre e do mesmo ensinamento. Enfim, não há discípulos sem condiscípulos. Ora, eis que os chamados socráticos, longe de formar uma escola ou mesmo um grupo de pensamento, 
tomam os caminhos mais diversos após a morte do mestre, disputam entre si a herança, e se tornam por sua vez os mais antagonistas chefes de escolas. como ser discípulo sem condiscípulos?

Temos portanto um esquema do seguinte tipo: cada discurso do discípulo é definido por uma dupla relação de afimação que se choca nos dois casos com sua negação: em face do mestre, a afimação "sou teu discípulo" se choca com a negação "não és meu discípulo porque não tenho discípulo algum"; em face dos condiscípulos a afimação "sou seu discípulo" se choca com a negação dos outros condiscípulos "não és seu discípulo porque sou eu que sou seu único discípulo".

Vejamos a que esta relação reenvia, primeiramente do ponto de vista doutrinal, em segundo lugar do ponto de vista do modo de discursividade próprio à palavra do mestre, e em terceiro do ponto de vista do modo de relação do discípulo com o mestre.

Do ponto de vista doutrinal, pode-se partir outra vez de nossa interrogação anterior: o mestre nada tem a ensinar, mas cada discípulo funda seu ensinamento sobre a palavra do mestre. Como é isto possível? Pode-se talvez sustentar uma tese, que por vezes foi defendida, segundo a qual cada socrático de algum modo se contentou em levar ao extremo uma tese de Sócrates e em desenvolver todas as suas consequiências. Em suma, reencontrar-se-ia facilmente aqui, e duma maneira pura e portanto quase caricatural, uma das "funçães" clássicas dos discípulos em relação ao mestre. O que no mestre era investigação, problema, aporia, interrogação torna-se no discípulo lição, doutrina, dogma. Aquilo que no mestre fazia a vida do pensamento, os conceitos que deveu constituir à medida que se impunham a ele os problemas, estas ferramentas se tornaram no discípulo os diferentes elementos de um sistema inteiramente incoerente e totalizante, sem falhas nem silêncios, e desenvolvendo a partir de alguns princípios iniciais a sequiência inteira das consequiências até seus limites. E como, no caso, o mestre confiara seu pensamento apenas em conversas das quais cada qual podia se reclamar, que havia portanto ainda mais "jogo" que ordinariamente na palavra do mestre, era lógico que fosse por doutrinas diversas e incompatíveis que este "jogo" podia ser denegado. A unidade (total, sistemática, universal) emprestada ordinariamente e a priori pelo discípulo ao pensamento do mestre não podia portanto no caso ser constituída e por assim dizer produzida senão por cada discípulo individualmente e separadamente dos outros; de tal modo que do mestre aos discípulos, de Sócrates aos socráticos, não é desta vez uma doutrina que foi constituída, mas tantas doutrinas unas quanto ouvintes ele tinha.

Não é possível entrar aqui nos detalhes dessa demonstração. Contentêmo-nos com um esboço, a propósito da ética, o único domínio sobre o qual estamos um pouquinho informados, domínio cuja fundação a tradição inteira concorda em atribuir a Sócrates.

Consideremos pois quatro discípulos de Sócrates, fundadores de escolas rivais, Aristipo chefe de fila dos Cirenaicos, Antístenes, inspirador dos Cínicos, Euclides, chefe de fila dos Megáricos, e Platão, fundador da Academia. Segundo Aristipo, "o fim é o prazer" que se confunde com "o bem" (9) ; segundo Antístenes, ao contrário, "O fim consiste em viver segundo a virtude"(10) que "basta para proporcionar a felicidade"'(11) e ele julgava, parece(12) , que o prazer era não bom, mas mau; segundo Euclides de Mégara o bem é aquilo que é uno, sempre semelhante e idêntico a si mesmo(13) ; segundo Platão(14), o bem é aquilo que preserva cada coisa e lhe é útil.

Ora, é evidente que nenhuma dessas teses enquanto teses sobre a natureza do bem pôde ser sustentada por Sócrates, não somente porque ele sempre nos é apresentado a interrogar seu interlocutor sobre a natureza de tal ou tal valor, sem jamais responder ele mesmo ${ }^{(15)}$, mas mais fundamentalmente porque jamais ele se interroga sobre a natureza do próprio "bem" enquanto tal, isto é, como princípio fundamental único e absoluto da conduta. Deve-se concluir que essas teses nada têm de socrático, que são invenções de discípulos cobrindo suas próprias doutrinas com o nome do mestre? Seria demasiado simples.

Com efeito, se apenas se inverte, em cada uma dessas teses, o sujeito e o predicado, constata-se então que elas se tornam autenticamente socráticas. Ao invés de serem teses sobre aquilo que é o bem (até mesmo sobre a natureza do "fim" ou do "soberano bem"), elas se tornam afimações sobre aquilo que é bem e reencontram então seu sentido propriamente socrático. Sócrates poderia com efeito conceder a Aristipo que o prazer é bom; poderia reconhecer com Antístenes que a virtude é boa e traz a felicidade; admi- 
tiria com Euclides que o bem é sempre idêntico a si e estaria de acordo com Platão sobre o fato de que é útil a cada coisa. Não se pode mostrar aqui por que a teoria ética de Sócrates poderia com efeito admitir cada uma dessas teses. Contentêmo-nos em esclarecer a diferença entre as teses concedidas pelo mestre e as sustentadas pelos discípulos.

As teses que Sócrates aprovaria de cada um de seus discípulos (por exemplo, o prazer é bom) não são fundadoras de uma teoria ética. Pois não existe tal fundamento em Sócrates. Em compensação, pode-se dizer que cada um de nossos quatro filósofos faz de cada uma dessas teses (por exemplo a tese: "o bem não é outra coisa senão o prazer") a tese fundadora de sua ética. Do discurso do mestre ao discurso do discípulo, as proposições, por simples inversão da posição do sujeito e do predicado na proposição definicional, mudam completamente de estatuto e de lugar na doutrina; eles se tornam os fundamentos primeiros, iniciais, axiomáticos de uma cadeia de razões que dela procede.

Mas ao mesmo tempo, e por conseqüência, estas teses que podiam coexistir no pensamento do mestre tornam-se contraditórias entre si na boca, ou antes sob o estilete, dos diferentes discípulos. Pois pode-se afimar a um só tempo o valor do prazer e o da virtude sem se contradizer, pode-se a um só tempo sustentar como verdadeiro que o bem é tudo aquilo que é uno e também aquilo que preserva cada coisa - e é mesmo, de algum modo, neste conjunto coerente de teses que consiste a teoria socrática. Em compensação, toma-se perfeitamente contraditório, e é aí que reside a contradição entre Aristipo e Antístenes, sustentar, por exemplo, que o bem é e não é outra coisa senão o prazer, ou que ele é e não é outra coisa senão a virtude. Vê-se portanto como, sobre o plano doutrinal, cada discípulo pode com todo o direito pretender fundar sua própria doutrina sobre a palavra do mestre e ter por inabalável que as dos outros discípulos que a contradizem traem esta mesma palavra, sem que ela própria possa ser tida por incoerente. Vê-se também aquilo que, da palavra do mestre ao escrito dos discípulos, se modifica: o discípulo toma como objeto de sua própria doutrina a palavra do mestre, mas, pensando-a sobre o modo da totalidade, ele faz desta palavra o momento de uma cadeia de verdades encadeadas entre si, dos primeiros princípios até suas últimas consequiências.
Tal é, portanto, a primeira explicação - doutrinal - que podemos dar do paradoxo do socrático, que reenvia e reproduz a relação das diferentes doutrinas do mestre à palavra inicial do mestre.

Mas o paradoxo do socrático pode reenviar ainda a um segundo tipo de explicação, o modo de discursividade próprio à palavra do mestre. Ora, vamos constatar que a estrutura das relações dos discípulos com o mestre reproduz muito exatamente o modo de enunciação da palavra do mestre. Contentêmo-nos, ainda aqui, com um esboço.

Sabe-se que o modo pelo qual Sócrates se dirige a seus interlocutores (e portanto a cada um de nossos discípulos da primeira geração) é um modo oral que tem quatro características.

Primeiramente, este modo é dual: Sócrates jamais se dirige aos homens em geral (é o que o opõe à maioria dos filósofos ulteriores), nem mesmo a seus concidadãos (é o que o opõe aos retores de seu tempo), nem enfim a um pequeno grupo de amigos (o que o distinguiria de Epicuro, por exemplo), mas sempre a um indivíduo determinado com quem dialoga em particular, segundo as particularidades deste indivíduo.

Em segundo lugar, este modo é dialético: dizer que é dialético quer dizer que, diferentemente de outros modos duais, coloca-se como princípio que jamais se deve admitir por verdadeiro senão aquilo a que o outro dá formalmente seu acordo e procura-se além disso estabelecer estas verdades a partir, e a partir somente, daquilo que o interloator já admite inicialmente como verdade.

Em terceiro lugar, este modo é "elêntico"(16) - isto é, refutatório. A posição que ocupa Sócrates na relação dual é, como se sabe, a do interrogador, enquanto coloca seu interlocutor na posição daquele que deve responder. Mas como Sócrates pretende nada saber, a única virtude imediata da interrogação só pode ser negativa: mostrar ao interlocutor que a tese que ele sustentava inicialmente como verdadeira é refutável, isto é, entra em contradição com outras teses mais fundamentais às quais é obrigado a dar seu assentimento. A interrogação socrática, portanto, põe à prova, pela refutação, a coerência absoluta das posições espontâneas do interlocutor.

Enfim, em quarto lugar, dado que as teses iniciais (as que vão ser postas à prova justamente) são deixadas à iniciativa do interlocutor, a única 
coisa que Sócrates exige dele é a parrhesia ${ }^{(17)}$, conceito essencial da prática socrática raramente posto em evidência. A parrhesia é o fato para o interlocutor de dizer o que pensa, o que pensa verdadeiramente, sem se preocupar nem com a opinião dos outros, nem com a coerência a priori desta opinião inicial com suas outras opiniões, mas comprometendo-se somente em aderir totalmente à verdade daquilo que diz. Esta exigência é não somente uma necessidade moral para Sócrates (não se poderia fazer sobre o interlocutor a prova necessária ao conhecimento de si sem esta exigência), mas além disso uma exigência epistemológica: é o que distingue a interrogação socrática da interrogação erística onde o que importa é vencer o adversário ou não ser vencido por ele, onde portanto cada qual escolhe sua posição inicial, não por parrhesia, mas por simples comodidade estratégica: no torneio com efeito, cada qual tenta adotar a posição mais fácil de defender, independentemente de todo compromisso com a verdade daquilo que é sustentado.

Tais são, portanto, as particularidades do modo de Sócrates se dirigir a seus ouvintes, seu "método" se quisermos: ele supõe o face a face com o outro, repousa sobre o princípio dialético do estabelecimento das verdades, põe à prova a coerência de seus propósitos e implica sua adesão à verdade desses mesmos propósitos.

Vê-se com evidência como esta estrutura é exatamente reproduzida no paradoxo do socrático face ao mestre e aos outros discípulos. A exigência de dualidade explica que cada qual possa se estimar no direito de se fundar sobre o acordo individual que o mestre deu aos propósitos que sustenta, sem jamais poder apoiar-se sobre um discurso com pretensão universal. A exigência dialética se traduz pelo fato de que cada qual não é dbrigado a admitir como verdadeiro senão aquilo que efetivamente admitiu no diálogo com o mestre, à exclusão de tudo o que teria sido concedido em diálogos com outros. A prova da coerência absoluta das teses iniciais com todos os seus consequientes se traduz doutrinalmente pelo fato de que cada discípulo, partindo efetivamente de uma opinião inicial, tenta fundá-la sobre seus primeiros princípios e impeli-la até suas últimas consequiências, preocupando-se somente com a coerência das teses no seio daquilo que se torna então um sistema filosófico. Enfim, a exigência de parrhesia explica as contradições entre os discípulos. Cada qual parte com efeito de uma pro- posição nem demonstrada nem demonstrável (por exemplo, sobre a natureza do bem), mas que the parece indiscutivelmente e indubitavelmente verdadeira, de um lado porque enuncia com parrhesia (o que era a única exigência do mestre), e de outro lado porque uma versão "flexível" - isto é, não sistemática - desta mesma tese foi com efeito admitida por Sócrates, como se viu.

Vê-se portanto como o próprio modo de enunciação e de transmissão da palavra do mestre, Sócrates, se reproduz na posição paradoxal ocupada pelo discípulo socrático, de um lado a seu respeito, de outro lado, a respeito de todos os outros discípulos.

Mas o paradoxo seria ainda mais claramente esclarecido de um terceiro modo, não mais sobre o plano das doutrinas, nem sobre o plano de seu modo de transmissão pelo mestre, mas muito simplesmente pelo tipo de relação entre o mestre e o discípulo.

Ainda aqui, não se pode entrar em toolos os detalhes. Contentêmo-nos em recordar que a própria doutrina como seu modo de transmissão (dual, probatório e franco) supõem que a relação de Sócrates com seus discípulos seja uma relação afetiva, como nos é lembrado por numerosos textos; a própria condição do êxito da refutação socrática é que o vínculo do discípulo ao mestre seja o amor, ao menos no sentido unilateral do amor do discípulo pelo mestre; esta relação particular do discípulo socrático com respeito a Sócrates é, como Foucault mostrou num sentido no Uso dos prazeres ${ }^{(18)}$, o inverso daquela que as regras tradicionais da corte e da iniciação punham ordinariamente (onde o mestre é o amante e o jovem aluno o amado) .

Como não ver nessa estrutura onde cada qual ama o mesmo mestre que nada the deixa transparecer ${ }^{(19)}$ e onde cada qual exige apenas para si e contra seus rivais o amor único de um mestre que permanece benevolente em relação a todos, mas não concede seu amor a ninguém, a própria estrutura de nosso paradoxo do socrático onde cada relação de afimação do discípulo como tal se choca com sua negação; face ao mestre, a afimação "sou teu discípulo" (que se traduza doravante "eu te amo") se choca com a negação "não és meu discípulo porque não tenho discípulo algum" (tracução: "hão te amo porque não amo ninguém") ; face aos condiscípulos a afirmação "sou seu discípulo" (tradução: "é meu amado") se choca com a ne- 
gação dos outros condiscípulos "não és seu discípulo porque sou eu que sou seu único discípulo" (tradução: "não és seu amado porque sou eu seu único amado") . Pode-se certamente pensar, em outra parte que não a filosofia, noutros exemplos de tal modo de relação do mestre com seus discípulos, constitutivo de um tal modo de relação dos discípulos entre si...

Assim, o paradoxo do discípulo socrático reproduz a um só tempo o modo de relação de todas as doutrinas ditas socráticas com a teoria do próprio Sócrates, o modo de discursividade próprio a sua enunciação pelo mestre (a refutação dialética) , e o modo de relação que o mestre entretém face a seus discípulos, a relação amorosa unilateral.

Vamos reencontrar estes três modos de reprodução do discurso do mestre pelo discípulo na nossa segunda figura, entretanto totalmente oposta à primeira, a do discípulo epicurista.

\section{O discípulo epicurista: o doente curado e psitacista}

Um primeiro fato em que se pode reparar quando se vem a abordar o discípulo epicurista é ainda um paradoxo. A filosofia de Epicuro nos foi transmitida principalmente pela obra de um discípulo, Lucrécio, que, no seu imenso poema, o de natura rerum, nos forneceu a mais completa exposição que até nós chegou, senão de toda a doutrina epicurista, ao menos de toda sua física. E entretanto esta filosofia é bem aquela do mestre. Em toda sua obra, Lucrécio multiplica as declarações de fidelidade incondicional, de obediência total ao mestre, e mesmo de servilismo. O mestre disse a verdade, ele foi um deus, Lucrécio não pode mais que repeti-la, ou traduzila melhor; duplamente: do grego para o latim com todas as invenções léxicas que isto supõe, da prosa rude e utilitária do mestre para os versos carregados de imagens e sedutores do discípulo.

Um outro fato: em 1884, em Oenoanda, no coração da Lícia, foi descoberto um imenso conjunto de pedras gravadas constituindo os restos de uma muralha sobre a qual um cidadão chamado Diógenes, que viveu no segundo século de nossa era, escrevera tendo como destinatários todos os passantes, compatriotas ou estrangeiros de passagem em sua povoação, um verdadeiro tratado completo (física e ética) de filosofia epicurista, do qual certos fragmentos ainda estão em vias de decifração. Ora, fato notável, constata-se que a filosofia do mestre está aí ainda inalterada; numerosos fragmentos de pensamentos de Epicuro mesclados à prosa do discípulo atestam uma vez mais a fidelidade absoluta do discípulo à própria letra do texto magistral. Estamos lidando, portanto, com um caso único na história da filosofia de uma doutrina que sobreviveu durante seis séculos ao menos e se difundiu em toda a bacia do Mediterrâneo sem que um iota da letra original se achasse modificado, ou mesmo atualizado, adaptado às circunstâncias, ao lugar, à época de seus discípulos. O discípulo não se dá mesmo como tarefa comentar ou explicar a dora do mestre, mas somente transmiti-la, em suma, repeti-la. Certamente pôde acontecer que tal discípulo, por exemplo, Hemarco, sucessor de Epicuro à testa do Jardim, ou Filodemo, que viveu em Nápoles no século I a.C., se tenha dado como tarefa prolongar ou completar tal ou tal ponto de doutrina que o mestre não tivera ocasião de tratar, mas em todo caso nenhum eco nos chegou de uma divergência qualquer entre o mestre e tal discípulo afastado no tempo ou no espaço, e, fato mais notável ainda, nem mesmo o eco da menor querela entre os discípulos ${ }^{(20)}$. A que atribuir esta longevidade inabitual da letra magistral, esta piedasa fidelidade de discípulos inteiramente submetidos a esta letra, e esta disciplina inaudita entre condiscípulos? A três tipos de razões ligadas entre si, e que reenviam, ainda desta vez, primeiramente ao modo de discursividade próprio à doutrina, em segundo lugar à própria forma desta doutrina, e em terceiro ao modo de relação que ela estabelece entre o mest re e o discípulo.

Qual é, portanto, primeiramente o modo de discursividade próprio ao enunciado da doutrina? Os textos do epicurismo que chegaram até nós não são tratados, propriamente falando, ainda menos meditações, diálogos ou mitos. Na sua imensa maioria, pertencem a um mesmo gênero literário, enunciado por um mesmo tipo de sujeito e destinado a um mesmo tipo de destinatário. Em todos os casos, os textos de Epicuro (as três cartas de seu punho que nos chegaram) e a própria obra de Lucrécio são discursos que expõem a doutrina epicurista como um conjunto acabado de verdades, um todo já constituído de doutrinas articuladas entre si, e cujo modo de enunciação não deixa lugar algum à dúvida, à interrogação ou à investigação. Neste 
sentido, são discursos dogmáticos (o que não os impede, aliás, de serem argumentativos). Em todos os casos, trata-se além disso de discursos pronunciados por um mestre e dirigidos explicitamente a um discípulo determinado (Heródoto, Meneceu, Pítocles no caso de Epicuro, Memius no caso de Lucrécio), ou seja, discursos enunciados do ponto de vista do sábio já possuidor e já praticante da verdadeira doutrina, a um discípulo que se trata de converter, guiar, ou fazer progredir na via de sua assimilação. Neste sentido, são discursos magistrais. Significativamente, o próprio Iucrécio, o discípulo por excelência, se dirige a seu próprio discípulo colocandb-se ele mesmo na posição assim definida do mestre. Duplo discurso de Lucrécio que se dirige ora como mestre onisciente ao discípulo que tenta converter, ora como discípulo convertido ao mestre, a fim de que o auxilie na sua obra de conversão. Em todos os casos, são discursos que não somente dizem ou pretendem dizer uma verdade já inteiramente constituída e transmiti-la àquele a quem se dirigem, mas que além disso o exortam, lhe ordenam esta conversão e se pensam eles próprios como tendo de fato, na prática, este efeito sobre seu destinatário. Eles não se enunciam com efeito como simples verdades que se trataria somente de compreender ou admitir, mas como atos ou práticas discursivas que, apenas pelo fato de serem ouvidas, compreendidas, adnitidas, mas também repetidas, memorizadas, praticadas pelo discípulo permitem transformá-lo em todo seu ser e lhe dão acesso à felicidade. Enfim, não somente um discurso que revela aquilo que é desde toda a eternidade, mas que além disso age sobre o ser de seu destinatário.

Fis portanto uma primeira explicação da estranha perenidade da letra epicurista através de seus discípulos: o modo de enunciação próprio à doutrina. Trata-se, como se viu, de enunciar um conjunto de verdades colocadas pelo mestre como sempre já-aí antes mesmo de sua enunciação, de um discurso que coloca portanto necessariamente aquele que o enuncia na posição de mestre convertendo de novo um discípulo, para fazê-lo aceder a um bem supremo que sem a doutrina lhe permaneceria proibido ou impossível. A estas particularidades do discurso epicurista está evidentemente ligada, em segundo lugar, a própria forma da doutrina que ele proclama.

Esta forma é certamente aquela de um sistema completo e acabado. Mais precisamente aquela de uma totalidade orgânica. A doutrina se apre- senta assim com frequiência sob a forma de resumos (pequenos ou grandes); ela se dá assim como podendo ainda e sempre ser condensada sem perder nenhuma das características da totalidade. Do mesmo modo, inversamente, ela pode sempre ser desenvolvida sobre tal ou tal ponto, com a condição de que a posição do ponto no conjunto, sua função no corpus das verdades, seja sempre lembrada. O mestre não se priva de resumir ele mesmo a doutrina para os iniciantes a fim de que possam de pronto ter o todo no espírito antes de entrar no estudo das partes; a fim de que o discípulo mais avançado jamais esqueça o conjunto, não se perca nos detalhes estudados por si mesmos separadamente de sua função de simples meios em vista da posse do todo da doutrina ${ }^{(21)}$. Daí o papel fundamental do aprendizado de coletâneas de máximas, a recitação de resumos, daí a importância dos exercícios de repetição feitos pelos discípulos, sozinhos ou em grupo(22) . Do menor resumo, modelo reduzido do todo, onde já se condensa toda a doutrina em quatro fómulas lapidares, que já sabe aquele que apenas acaba de entrar no Jardim e que fica à disposição permanente de todo discípulo como tantos vade-mecum indispensáveis face a todas as situações da existência, até os trinta e sete livros da Física escritos por Epicuro à destinação dos mais avançados, o discípulo se desenvolve como um corpo em expansão: ele não progride, com efeito, por uma acumulação progressiva de verdades, segundo o encadeamento irreversível da ordem das razões e ao longo do eixo unilateral de um discurso que leva dos primeiros princípios às últimas consequiências, tal como se pode ver em Aristóteles, por exemplo, mas segundo um modelo biológico do crescimento, de uma totalidade orgânica se dilatando quantitativamente, do interior, e para tudo dizer por assimilação, sem que a relação interna entre seus órgãos, o funcionamento recíproco de suas partes e a organização do conjunto se achem alterados, desde o concentrado mínimo da doutrina até sua expansão máxima.

Vê-se aí uma segunda explicação da estranha perenidade da letra epicurista através de seus discípulos: um sistema que se transmite sempre segundo a idéía do todo que ele constitui e que, a cada momento de seu aprendizado pelo discípulo, é sempre inteiramente assimilável como um todo sem vazios ou lacunas, não pode senão produzir um discípulo repetidor. Mas há para isto uma outra razão que reside não no modo de discursividade 
no qual se exprime a doutrina, nem na forma que ela toma, mas, em terceiro lugar, na relação que ela estabelece entre mestre e discípulo.

Já se sublinhou de passagem que o mestre menos instruía o discípulo do que o transformava. Mas de que transformação se trata e qual é exatamente o vínculo que institui o discurso filosófico entre mestre e discípulo? Muito exatamente o do médico ao doente. A filosofia é com efeito definida pelos epicuristas como medicina: ela cura os homens da situação inicial e necessária de dor e de infelicidade na qual se acham ordinariamente. O homem, isto é, aquele que ainda não entrou no Jardim, está arruinado por diversas doenças, quatro principais, o desejo vão que se entretém ele mesmo ao infinito sem jamais atingir seu bem, o temor dos deuses, o da morte e o da dor. Para estes males, há diversas causas, dentre as quais a ignorância em que se encontra a maioria dos homens sobre a natureza das coisas, agravada pelos falsos remédios que se auto-prescrevem, por exemplo, o recurso aos mitos da religião popular, os quais os doentes esperam que acalmem seus temores, mas que não fazem senão explorar sua ignorância e aumentar o número e a gravidade de seus vãos temores. Para estes males, há apenas um verdadeiro remédio, a prática da verdadeira filosofia(23) . Esta começa pela assimilação, em todos os sentidos do termo, do quádruplo remédio (tetraphamakos), tratamento polivalente susceptível de responder com urgência à maioria dos sintomas do doente, mas que ainda não ataca as causas da doença, principalmente a ignorância da natureza das coisas. Mas, já no tetrapharmakos, toda a doutrina está concentrada. Pouco a pouco, à medida dos progressos do doente, e segundo a dose exigida por suas necessidades, o médico prescreverá um aprofundamento da cura permitindo-lhe ir até o tratamento radical das causas da doença e levará o paciente-discípulo até o conhecimento completo da natureza das coisas (isto é, da física) . O mestre, portanto, não é nada senão um médico e esta posição que ocupa não é outra senão o ponto que ele próprio atingiu, a sabedoria, isto é, o fim da filosofia, no tríplice sentido da palavra (acabamento, limite e fim) e ao mesmo tempo o ponto onde ele pode levar o discípulo, curando-o; este poderá então curar outros homens que aceitem a recompensa dele: a cura filosófica. É precisamente o destino do discípulo tornar-se ele próprio médico. Exemplar neste aspecto é, uma vez mais, o caso de Lucrécio. Não podendo, como discípulo epicurista, senão repetir o discurso do mestre que tem como destinatário aquele que pretende curar, Memius, ele faz ao mesmo tempo a teoria de sua própria prática de poetização do discurso do mestre e inventa uma nova dimensão da própria terapêutica: assim como as amas de leite untam com mel a taça contendo o remédio amargo para a criança doente, do mesmo modo ele unta com o mel de sua poesia a demasiado amarga doutrina física epicurista para o indócil dedicatário ${ }^{(24)}$ - Tal é o gênio de Iucrécio, saber ao mesmo tempo ser mestre de um discurso inédito, sem sair de seu papel de discípulo condenado à simples reprodução do discurso do mestre.

Seja, dir-se-á, a letra se conserva porque por ela se transmite o savoirfaire que permite ao mestre-médico curar os males da humanidade e formar discípulos. O discípulo se torna ele próprio mest re quando, curado definitivamente dos males dos quais sofria como homem, ele atinge, ao mesmo tempo que o estado irreversível de felicidade, a posição inexpugnável do sábio. Se este é bem o destino do discípulo epicurista, tornar-se mestre e transformar outros discípulos em mestres ao infinito, se esta é bem a cadeia ordenada que junta através das gerações cada discípulo ao mest re que o formou e curou, e todos os discípulos ao mestre primeiro, elo inicial e principal da cadeia, Epicuro, que os formou todos, uma questão se põe: quem portanto formou - e curou - o próprio Epicuro? A resposta de nossos textos ainda aí é sem ambigüidade e reproduz um esquema clássico nesta figura: o mestre é autoformado e não reconhece ele mesmo mestre algum; além disso, seus próprios discípulos afi mam que o mestre absoluto não foi discípulo de ninguém"(25) : "Apolodoro diz dele (Epicuro) nas suas Crônicas que foi discípulo de Nausifane e de Praxifane. Fle próprio o nega na Carta a Euríloco e afirma que não foi discípulo senão de si mesmo. E ele e Hêrmaco (seu primeiro discípulo) negam mesmo que tenha existido um Leucipo filósofo, do qual alguns (...) dizem que foi o mestre de Demócrito' (26) . Pode-se certamente pensar em outros exemplos de uma tal cadeia de transmissão obedecendo a este mesmo esquema, onde cada discípulo forma outros conforme uma tradição regrada, práticas de formação e de cura e uma doutrina constituída que remontam ao mestre, instaurador destas regras, tendo praticado sobre si mesmo esta formação e esta cura de acordo com a doutrina que ele mesmo constituiu....(27) 
Entre estas duas figuras extremas do discípulo socrático e do discípulo epicurista, há lugar para uma terceira figura, a do discípulo aristotélico.

\section{O discípulo aristotélico: o comentador insatisfeito}

É bastante difícil caracterizar numa palavra o discípulo de Aristóteles. É mais fácil caracterizar aquilo que se pode chamar o "aristotelismo", que é uma tendência recorrente ao longo da história da filosofia, aquela que consistiu em considerar a autoridade do texto aristotélico como um dos critérios possíveis da verdade. Como se constituiu este aristotelismo e o que é da posição do aristotélico assim definido com relação ao mestre e a seu discurso?

Ao contrário do socratismo, o aristotelismo não se constituiu desde a morte do mestre pela escrita e sistematização, por parte dos discípulos, dos laços pessoais que ligava cada um ao mestre; é muito tempo após a morte de Aristóteles e completamente de modo independente de algum vínculo pessoal com seus discípulos imediatos que o aristotelismo se constituiu. Ao contrário do epicurismo, o aristotelismo não se constituiu pela manutenção contínua de uma tradição doutrinal literal remontando ao mestre; a tradição aristotélica é ao contrário cheia de rupturas, cheia de some de fúria; enfim, o aristotelismo tem uma história, ao menos no sentido trivial de que cada época da história da filosofia teve um Aristóteles à sua própria imagem. Assim, como o socratismo, o aristotelismo diz-se no plural: os discípulos são numerosos e invocam o nome do mestre em sentidos opostos, lançam uns contra os outros a autoridade de seu nome, à guisa de argumento ou refutação. Mas como no epicurismo, é por um recurso constante, permanente e por assim dizer único à própria letra do texto como figura absoluta da autoridade que a posição do discurso do discípulo é possível. Esta relação ambígua com o texto do mestre, ao mesmo tempo fonte primeira da verdade, e entretanto fonte de verdades múltiplas, só é possível portada por uma terceira figura do discípulo: nem o discípulo criador de doutrinas (como o socrático), nem o discípulo repetidor da doutrina do mestre (como o epicurista), mas o discípulo intérprete. O aristotelismo pode, com efeito, ser definido provisoriamente como a interpretação, indefinidamente renovada e discutível, da doutrina ou dos textos de Aristóteles. É portanto um amontoado complexo e variável de teses, glosas e teorias, onde evidentemente se entremearam diversamente, segundo as épocas, as partes da tradução, do comentário e da adaptação do texto aristotélico, mas onde certas constantes podem ser percebidas permitindo desenhar uma figura do aristotélico. Ela aparecerá melhor se recordarmos muito brevemente como se constituiu o aristotelismo.

Após a morte de Aristóteles (422 a.C.. ), ainda que o Liceu que fundara permanecesse churante quatro séculos um importante centro de pesquisas, principalmente em física e em retórica, não parece que tenha havido filósofo importante na direção da escola, salvo seu sucessor imediato Teofrasto, cujo nome permaneceu muito tempo associado ao do mestre. Aliás, se a autoridade de que desfrutava Aristóteles durante todo este período permanecia imensa, ao menos tanto quanto a de $\mathrm{Platão,} \mathrm{parece} \mathrm{que} \mathrm{ela} \mathrm{repousava}$ principalmente sobre as obras publicadas em vida por Aristóteles (sobretudo diálogos à maneira de Platão, hoje perdidos). A obra que conhecemos de Aristóteles, e que devia estar na origem do aristotelismo ulterior, era em sua maior parte ignorada pelos antigos; é verdade que se tratava mais frequientemente de simples notas, mais ou menos redigidas e classificadas, escritas por Aristóteles em momentos diversos de sua carreira com finalidades de ensino, e que o estado disperso ou o estilo elíptico, mesmo a dificuldade do assunto, tornavam impróprios para a publicação fora do círculo da escola. A maneira pela qual este importante lote de manuscritos praticamente perdidos chegou em 60 a.C. às mãos de Andrônico de Rodes, o décimo e último escolarca do Liceu, era desde a Antiguidade um assunto de lenda. É sempre certo que Andrônico reuniu esta massa de documentos para dela fazer livros publicáveis: essa publicação foi acompanhada, portanto, de um trabalho de classificação e de organização racional do saber. Ele dava assim ao mundo o que se chama correntemente o corpus aristotélico, que devia progressivamente eclipsar a dbra publicada pelo próprio Aristóteles, e ia constituir o conjunto de textos profanos mais lido e comentado de toda a História. Este gesto pode ao mesmo tempo ser considerado como a certidão de nascimento do "aristotelismo". Duas de suas constantes, com 
efeito, já estão aí presentes: a sistematização do texto aristotélico num conjunto podendo servir de fundamento a uma unidade doutrinal; mas, ao mesmo tempo, uma vontade de retorno (para além da tradição) à letra do texto de Aristóteles considerada como garantia de verdade. Esta primeira edição teve ademais um outro efeito determinante para toda a história do aristotelismo: dada a distância entre esta foma editorial garantindo a unidade de uma obra (aparentemente sistemática: livros de lógica, "organon" geral da ciênciar livros de física, seguida dos de metafísica etc) e esta letra (cursiva, inacabada, dificultosa e até incoerente), o aristotelismo, em toobs os momentos de sua história, não poderá instituir-se e perpetuar-se senão pelo viés do comentário, destinado a cumular tanto quanto possível esta distância. Tais são as três características fixas, aliás ligadas entre si, do aristotelismo (sistematização, retomo à letra, comentarismo indefinido) do qual se poderia seguir os meandros ao longo de treze séculos de história.

Desde os primeiros séculos, com efeito, onde já se efetua um verdadeiro trabalho filológico (comparação das cópias, estabelecimento de variantes, conjecturas: por exemplo, a prática de Alexandre de Afrodísia, chamado o "segundo Aristóteles" ou "o Exegeta", visa mais frequientemente a esclarecer Aristóteles por ele mesmo, moldando o mais possível o comentário sobre os textos originais) até Guilherme de Moerbeke que, no século XII, cumpriu um enésimo retorno à letra pela transcrição em latim, palavra por palavra, do texto grego a pedido de São Tomás de Aquino, passando pelos árabes al-Fârâbî, chamado "o segundo mestre" (depois de Aristóteles), por suas "paráfrases" das Categorias ou dos Analíticos, ou Averróes, que nos seus comentários de Aristóteles ("grandes comentários" que recopiam e explicam o texto passo a passo, "comentários médios", que o parafraseiam livremente, e "epítomes" que o resumem), quer promover um retorno ao "verdadeiro" Aristóteles, "corrompido" pela leituras platônicas, aparece, a despeito das oposições de cultura e doutrina, uma constante histórica: a figura do aristotélico cujos três traços já tinham se distinguido desde a publicação do corpus por Andrônico.

Primeiro traço, o comentário. Para o aristotélico, a prática da filosofia, isto é, a busca da verdade, não é possível senão através da leitura e do comentário da obra de Aristóteles, posta como doutrina acabada e intempo- ral. Cada palavra, cada frase, cada capítulo, cada dbra deve poder ser decifrada e ter um sentido enunciável, sentido supremo que excede sempre o sentido manifesto, manifestamente obscuro ou equívoco, sentido supremo entretanto autorizado e garantido por este único sentido manifesto, que é ao mesmo tempo e paradoxalmente o princípio e o fim do comentário, sua pedra de toque ao mesmo tempo que seu objeto. Este comentário não é, portanto, uma simples repetição, mas a busca indefinida e inacabável de um sentido original, de uma autenticidade perdida, de uma coerência suprema e primordial à qual o discípulo já não tem acesso, porque a espessura da história, a opacidade dos textos e a inflação das mediações dos outros comentários lhe barram o acesso. Este comentarismo repousa, portanto, sobre o mito hermenêutico da verdade original perdida a ser reencontrada nos retalhos precários de um texto disperso e sob as camadas de mediações sedimentadas pela tradição. Ele tem, portanto, como se viu, duas práticas conseqüentes, repousando elas mesmas sobre seus mitos respectivos.

Além do comentário do texto de que dispõe, o aristotélico deve com efeito sistematizar permanentemente a obra que comenta, fazer dela um todo coerente, quer sobre o plano editorial, quer sobre o plano doutrinal. Esta prática repousa sobre a ilusão da unidade sistemática do conpus, ilusão tenaz a despeito da forma dispersa, aporética, aberta na qual se apresentava a letra do corpus, mas ilusão remanente porque fundada sobre um mito mais poderoso que todos estes signos manifestos, o da unidade absoluta, da univocidade primordial, da coerência total, da totalização englobante e compreensiva da Verdade na sua origem. Deste ponto de vista, pode-se dizer que o fim (sem dúvida provisório) do aristotelismo pode ser datado de 1912, data da publicação dos trabalhos do historiador W. Jaeger, que desmontando no corpus aristotélico a série de camadas superpostas escritas pelo mestre em diferentes momentos de sua vida e de seu pensamento destruía a ilusão da unidade de um corpus que um dia saíra acabado, com armas e bagagens, do espírito de Aristóteles e assim restituía definitivamente (ou mais provavelmente provisoriamente) Aristóteles à história da filosofia.

Enfim, estas duas práticas do comentário e da totalização não seriam possíveis sem uma terceira, a do retomo à letra. Pois, certamente, o principal obstáculo que o aristotélico encontra em seu trabalho de comentário é a 
massa indefinida dos outros comentários como outras tantas traições; e a principal dificuldade que experimenta em compreender, isto é, em abarcar a obra do mestre num todo coerente, é a espessa acumulação das outras interpretações que barram o acesso ao texto e à verdade original. Daí a palavra de ordem periódica lançada pelo aristotélico: retornemos enfim de uma vez por todas à letra do texto de Aristóteles; desprezemos os comentários e interpretações; deixemos nossa própria interpretação e nosso próprio comentário modelar-se sobre a letra nua do texto original, travestida pelas traições, pelos prejuízos, em suma, pela história. A esta história, com toda certeza, o próprio discípulo não pensa pertencer, do mesmo modo que, por hipótese, ele exclui da história o mestre original, mas é a ela que são votados e reenviados todos os outros comentadores. O aristotélico reclama, portanto, o puro face a face transcendental com a letra do texto, enfim acessível sem mediações supérfluas e deformantes, o texto enfim desembaraçado dos contra-sensos dos outros aristotélicos, o texto enfim devolvido a si mesmo para além da "tradição" e aquém da história.

Estes três tipos de práticas e estes três mitos (comentar para reencontrar enfim um sentido original pensado como verdade perdida; sistematizar para reencontrar atrás dos retalhos esparsos, os fragmentos disseminados ou as pobres migalhas despedaçadas das quais as contingências da história nos fizeram herdeiros, a coerência e a totalidade de uma obra pensada como verdade originariamente una e unívoca; enfim retornar à letra para contornar a soma dos outros comentários que a traem e reencontrar neste face a face enfim possível com o texto nu a verdade enterrada) certamente já não alimentam os aristotélicos desde Jaeger. Talvez valha a pena notar entre parênteses que eles continuam e continuarão sem dúvida a alimentar a prática de leitura de todos aqueles que abrigam seu próprio dogmatismo por trás do biombo de uma hermenêutica. Com toda certeza pensa-se em Heidegger, o grande mestre contemporâneo desta leitura taumatúrgica dos textos gregos ${ }^{(28)}$.

É possível sem dúvida mostrar, ainda ali, como estes três aspectos indissociáveis da prática do discípulo aristotélico (comentário, sistematização, retorno à letra) encontram apoio tanto na própria doutrina quanto na maneira como aí se concebe a relação do mestre ao discípulo. Aqui, pode-se apenas esboçar alguns reparos.

Sobre o plano doutrinal, ao contrário de Sócrates, Aristóteles não identifica o bem supremo do homem com a compreensão racional por parte de cada um de sua própria conduta e a exigência de coerência absoluta na prática ética; ao contrário de Epicuro, Aristóteles não identifica este bem supremo com a perpetuação de uma vida sem perturbações, sem males e sem temores; mas coloca que este bem consiste para o homem na perpetuação, tanto quanto possível, de uma vida contemplativa, isto é, o ato de conhecimento acabado de tudo aquilo que é e se dá a compreender. A filosofia não é portanto nem interrogação crítica como para Sócrates, nem prática terapêutica, como para Epicuro, mas processo, movimento de conhecimento visando seu próprio fim, ou seja, seu ato, o conhecimento acabado. Como não reconhecer neste ideal enunciado pelo mestre a própria prática do discípulo: o aristotélico é com efeito aquele que identifica a felicidade com o conhecimento completo e em ato, onde se acaba e se unifica o próprio movimento que para aí leva, e é bem a própria prática do discípulo aristotélico sobre o texto de Aristóteles, considerado como a própria fonte da verdade, o objeto a conhecer donde viria o bem prometido, o objeto incessantemente recomeçado e nunca acabável, cuja posse em ato se identificaria para o homem com seu bem supremo. Vê-se aqui claramante que o mestre pensa as coisas e seus discípulos o pensamento do mestre.

Sobre o plano da relação mestre-discípulo, Aristóteles, ao contrário de Sócrates, não concebe esta relação sobre o modo da relação amorosa dual (amante/amado), de tal modo que permita ao mestre interrogar cada um naquilo que tem de único; ao contrário de Epicuro, Aristóteles não concebe a relação do mestre ao discípulo sobre o modo da relação médico/ doente, de tal maneira que permita ao mestre, curando seu ouvinte, formálo de um só golpe à prática terapêutica; nem relação amorosa, nem relação médica, a relação do mestre ao discípulo é essencialmente para Aristóteles uma relação de ensinamento, como se pode ver na teoria da transmissão do discurso da ciência tal como podemos lê-la nos Segundos Analíticos. Poderse-ia então correr o risco de ver na história dos discípulos aristotélicos como que a tentativa, jamais acabada, de realização do ideal que ali é descrito: um 
mestre que tudo sabe questionando um discípulo quase totalmente ignorante e não colocando verdade alguma sem o acordo explícito do discípulo. É normal que a este modelo corresponda a figura do discípulo que vimos; ao mestre Aristóteles é assim emprestada a priori a posse total do saber total, mas é ao discípulo, passo a passo, e apoiando-se somente sobre aquilo que disse (ou escreveu) o mestre que cabe atingir esta totalidade no próprio discurso do mestre, na recolagem jamais completamente acabável da obra a si mesma. Pode-se ainda pensar aqui, em muitos outros exemplos, fora da filosofia, de um mestre cujo ensinamento e corpus dos escritos se edite tardiamente e mesmo após sua morte, e cujos discípulos se dêem por tarefa reconstituir indefinidamente a letra à qual retornam infinitamente, compreender completamente o pensamento uno, e comentar para sempre a obra que excede sempre seus próprios comentários.

Vamos ao balanço: três tipos de discípulos, os primeiros se dilaceram entre si, se abrigam por detrás do nome do mestre, sistematizam seu ensinamento além do que autorizava, mas criam uma obra autêntica; os segundos são mais atilados e fiéis, mas levam a fidelidade até o psitacismo; os últimos sistematizam como os primeiros o ensinamento do mestre, mas ao mesmo tempo, animados de fidelidade como os segundos, se consagram ao comentário do mestre. Estas figuras estão com certeza em oposição, mas vimos que reproduziam a cada vez a forma totalizada da doutrina do mestre, seu modo de transmissão (maiêutica, protrética e epistêmica ${ }^{(29)}$ e o modo de relação que ligava o discípulo ao mestre (o amor, a cura, o ensinamento) . A estas constantes que são outras tantas diferenças pode-se acrescentar a constância por excelência, aquela por onde se identificam: o discípulo jamais pode reproduzir o discurso do mestre senão sob a figura da totalidade.

Haveria outros tipos de discípulos que não entrariam em nenhuma das figuras acima? Talvez sim. Mas talvez não. Pois no fundo os três grandes tipos de discípulos que estudamos não reenviam aos três únicos modos possíveis de fillosofar? Não se poderia dizer com efeito que nossas três doutrinas fornecem os três únicos modelos daquilo que pode ser a filosofia? Toda filosofia não é, com efeito, quer como a socrática, de essência crítica, isto é, visa a pôr à prova as falsas certezas, quer, como a epicurista, de essência liberadora, isto é, visa a curar-nos e livrar-nos de nossos males, de nossas paixões e de nossos grilhões, quer como a aristotélica, de essência alética, isto é, visa unicamente à verdade e portanto à constituição de um conjunto completo de conhecimentos?

Voltemos, pois, ao nosso ponto de partida. Se G. Lebrun é bem o mestre que muitos vêem nele e se todo mestre se inscreve numa das figuras históricas que descrevemos, então é evidentemente sob a primeira figura que se deve alinhá-lo. Compreender-se-ia assim o paradoxo. É por ele que muitos aprenderam a ser eles mesmos. É no pensamento deles, não no seu, que os formou. E as doutrinas são coisas deles e não sua. É por isso que alguns deles o acusam hoje daquilo que são por seu intermédio? Mas é preciso que se resignem a procurar um outro bode expiatório para este mau processo: pois ele já aceitou a proposta - a mesma que recusou Sócrates ${ }^{(30)}$ de deixar sua pátria (o Brasil) à qual era tão carnalmente ligado e à qual tanto tinha dado.

Abstract: The focus of this paper is three typical figures of disciple in Ancient Philosophy: the Socratic or "the jealous son", the Epicurean or "the healed disciple, but psitacist", and the Aristotelian or "the unsatisfied exegete".

Key-words: Ancient Philosophy - master - disciple - Socrate - Epicureanism - Aristotelism. 


\section{Notas}

(1) Ver Platão, Apologia, 33 a-b.

(2) G. Lebrun, 3, p. 241.

(3) A priori, um lugar deveria ser dado também ao estoicismo que oferece aparentemente um modelo diferente de relação de discípulo a mestre; a cada geração a doutrina muda, se transforma, se adapta; cada discípulo se tornando mestre por sua vez dá-Ihe uma direção inédita. Há, portanto, quase tantos estoicismos quanto gerações de estóicos. Não nos parece entretanto que estejamos lidando com uma figura típica do discípulo.

(4) É já a questão, ou o espanto, dos Antigos, por exemplo Cícero (De oratore, III, XVI, 61): "como de Sócrates tinham nascido de aloum modo muitas escolas filosóficas, que nessas discussões variadas, opostas, levadas adiante em todos os sentidos, se tinham ligado cada qual a uma idéia, viu-se desenvolver uma série de famílias por assim dizer (quasi familiae), divididas quanto às opiniões, muito distintas e diversas, embora todos esses filósofos quisessem ser ditos continuadores de Sócrates e acreditassem sê-lo". Santo Agostinho escreve mais vigorosamente: "Os socráticos bem que divergiram entre si no que concerne ao fim último. É difícil conceber que os discípulos de um mesmo mestre tenham podido chegar a isto: uns, como Aristipo, dizem que o prazer é o soberano bem, enquanto outros, Antístenes por exemplo, ident ificam-no à virtude." (Cidade de Deus, VIII, 3) .

(5) Ao menos segundo os testemunhos da Antiguidade tardia. É assim que Diógenes Laércio fala não somente de "sucessores" (di a dexa msnol : em II, 47, onde cita Platão, Xenofonte, Antístenes, depois Esquino, Fedon, Euclides, Aristipo), mas também de "discípulo" (ma qht» : : em II, 20, a propósito de Esquino, em II, 74, a propósito de Aristipo) ou de "condiscípulos" (s umma qhtf j : em VI, 2, a propósito de Antístenes e de seus ouvintes) ou de "aluno" ( $\mathrm{k}$ roat»j : aquele que escuta e obedece: em II, 48 a propósito de Xenofonte). Em compensação, as primeiras gerações empregam significativamente um outro vocabulário: Sócrates é qualificado por seus ouvintes de "amigo" (Platão, Carta VII, 324 e) , ou de "camarada" ('t'a 〈r oj : Aristóteles, Retórica II, 1398 b 31), e eles são nomeados selus "companheiros", como diz em todas as páginas Xenofonte, a saber of s undia tr .bontej aqueles que passam seu tempo com ele, ou of s unOntej, aqueles que vivem com ele, com todas as conotações que esta idéia supõe.

(6) Lembrêmo-nos do protesto de Sócrates na Apologia de Sócrates contra as insinuações de corrupção em relação àqueles que seus caluniadores chamam seus discípulos (ma qhtfj)); ele precisa: "ora, jamais fui eu mesmo mestre (didf scal oj ) de ninguém" (33 a) . Esta dupla denegação (não sou mestre, ninguém é meu discípulo) é repetida algumas linhas mais longe (33 b: "jamais prometi ensinar, nem ensinei de fato, nada que se aprenda - $\mathrm{mf}$ qhma - a nenhum dentre eles").

(7) O "testemunho"de Platão é sobre este ponto confirmado por Xenofonte: Memoráveis, 1, 2, 3 .

(8) Esta palavra significa também existência em comum, até mesmo relação sexual.

(9) Ver principalmente a exposição de Diógenes Laércio II, 87-88.

(10) Diógenes Laércio, VI, 104.

(11) Ibid, VI. 11.

(12) Ibid., IX, 101 e Sexto-Empírico, Adv. Math., XI, 73 etc.

(13) Cícero, Acad. pr.II, XLII, 129. "Os Megáricos diziam que o bem é somente aquilo que é uno, sempre semelhante e idêntico a si". Ver também Diógenes Laércio II, 106, que atribui expressamente esta tese ao próprio Euclides.

(14) Tal é a definição do Bem que se encontra na República, X 608 e. É a única que se encontra, para falar propriamente, na República, da qual se sabe que um dos temas essenciais dos livros centrais é justamente a investigação de uma tal deteminação, principalmente através das três "imagens" dos livros VI-VII lo Bemsol, a analogia da linha e a alegoria da caverna).

(15) Certas passagens das Memoráveis deixam entender uma participação mais ativa de Sócrates no trabalho definicional que aquela que nos apresenta Platão nos diálogos de juventude, os únicos a serem propriamente "socráticos". Dito isto, Xenofonte confirma que Sócrates era acusado por seus interlocutores de jamais definir ele mesmo as "qualidades morais" (Mem. IV, 4,9-10) e mais geralmente o bem sobre o qual pretendia interrogar os outros (ver também Mem. I, 2, 3 e 17-18, assim como o diálogo pseudo-platônico Clitofon, 410 b-c) . 
(16) Do grego a egcoj, refutação, procedimento dialético sem dúvida "inventado" e teorizado, em todo caso praticado, por Sócrates. Sobre a teoria do élenchos, poder-se-á reportar-se a $R$. Robinson, (4, pp. 1-60) e aos diversos artigos de $G$. Vlastos (por exemplo: 6, pp. 51-8 e 5, pp. 27-58).

(17) Sobre a parrhesia e sua importância na dialética socrática, ver Platão, Laques 189 a, Protágoras 331 b-c, Górgias 487 a 3 e 495 a, Cármides, 173 d, Críton, 49 a-b; assim como os comentadores citados na nota precedente.

(18) Ver o capítulo 5 de L'usage des plaisirs (Foulcault 1) .

(19) Lembrêmo-nos da famosa "impassibilidade"de Sócrates quando o belo Alcibíades penetrara furtivamante em seu leito (Platão, Banquete, 217 a - 219 e) .

(20) Não se pode contar como "querelas" as raras discussões das quais se fazem eco algumas testemunhas, aliás discutíveis, por exemplo para saber se há um quarto "critério de verdade" (Diógenes Laércio, $X, 31$ ) ou se a desejabilidade do prazer se conhece por sensação imediata ou segundo a "pré-noção" que temos do prazer (Cícero, De finibus, I, 9, 30.ss).

(21) A "carta a Heródoto" se apresenta assim como um "resumo" (epitomé) da física, resumo cuja dupla função é explicada por Epicuro desde as primeiras linhas. Aliás, o catálogo das obras de Epicuro segundo Diógenes Laércio (X, 2728) compreende um "grande resumo" e um "pequeno resumo".

(22) Ver por exemplo o estudo de I. Hadot $(2$, p. 347) e de W. De Witt (7).

(23) Sobre o filósofo médico no epicurismo, ver Epicuro, Sentença vaticana 54, Porfírio, ad Marcellam 31 (Usener fgt 221), Diógenes de Denoanda, fgt 2, 4-5 (Chilton) etc.

(24) De nat. rer., IV, 11-25.

(25) Sabe-se que não é assim. Os testemunhos que estimam sua formação são numerosos, mas além disso parece impossível que ele não tenha "aprendido" algo do atomismo de seus fundadores, por exemplo (Leucipo e Demócrito) .

(26) Diógenes Laércio, X, 13, trad. A. Laks. Sobre a autoformação ver também Cicero, de nat. deorum I, 26, 73: "Entretanto Epicuro desprezava soberbamente este platônico (Pânfilo), tanto temia parecer ter sido algum dia discípulo de quem quer que fosse..." (e a seqüência a propósito de Nausifane; ver também a este propósito Sextus Emp., adv. math. I, 4, ver a trad. de Iaks p.68: "suponho que os linguarudos vão pensar que fui mesmo discípulo da mecusa, porque a escutei em companhia de alguns jovens que se recuperavam da bebedeira.")

(27) Notemos sobre este ponto a oposição de nossas duas primeiras figuras magistrais. O mestre socrático não se quer mestre e não admite que forma seus discípulos: "você sabe tudo, nada sei, nada tenho a ensinar", diz ele; em oposição, o mestre epicurista se quer tão mestre que não admite ter sido formado: "você nada sabe e eu tudo sei, sem jamais ter aprendido nada com ninguém".

(28) Pode-se também pensar na prática de certos filólogos que pretendem estabelecer ou editar (enfim) o verdadeiro texto, finalmente legível porque devolvido a si mesmo, a despeito das traições, até dos complôs, de todos os outros. A mitologia desta hermenêutica é próxima da de Heidegger, embora possa ser-lhe oposta em certos de seus dogmas ou de suas conclusões; elas repousam sobre os mesmos pressupostos, tanto mais fascinantes e captatores num caso como no outro quanto o texto manifesto que serve de pretexto é manifestamente mais reduzido ou fragmentário, quanto a origem perdida e reencontrada está mais enterrada e se dissimula por detrás da própria língua, posta como originariamente unívoca e transparente, numa época auroral e dourada onde o sentido próprio ainda era de rigor.

(29) Ao mesmo tempo e sobretudo, constata-se que estes três tipos de discípulos reenviam à maneira pela qual cada uma das doutrinas concebe a essência da transmissão do saber. No socratismo, o saber não se transmite propriamente falando, é o aluno que aprende sozinho e que, sob a condução do mestre, não pode senão buscar e encontrar suas próprias verdades (é a famosa maiêutica) ; a este modelo de ensinamento responde evidentemente a idéia de um discípulo que invoca o mestre e batiza com seu nome todas as verdades que descobre em si mesmo. No aristotelismo, o sistema da ciência é descrito nos Segundos Analíticos: o mestre que tudo sabe questionando um discípulo quase totalmente ignorante e não colocando verdade alguma sem o acordo explícito do discípulo. É justo que a este modelo corresponda a figura do discípulo que nós vimos; ao mestre é emprestada a priori a posse total do saber total, e é portanto a constituir esta totalidade a partir do próprio discurso do mestre que é consagrada a obra do discípulo, eterno comentador. Enfim, no epicurismo, o discurso do mestre já sendo, a priori, o de uma totalidade fechada (o mestre se formou sozinho), o discípulo já não tem que constituí-la, ele só pode fazê-la sua repetindo-a ao infinito, ou tornando-se ele mesmo o mestre médico.

(30) Ver Platão, Crítão, principalmente 52 b e seg. 


\section{Bibliografia}

1. Foucault, M. L'usage des plaisirs. Paris, Gallimard, 1984.

2. Hadot, I. Epicure et I'enseignement phi losophique hel lénistique et romain. In: Actes du Congrès de I'Association Guill laume Budé. Paris, Les Belles Lettres, 1970.

3. Lebrun, G. La patience du concept. Essai sur les discours hégélien. Paris, Gallimard, 1972.

4. Robinson, R. Plato's Early Dialectic. Oxford, Clarendon Press, 1953.

5. Vlastos, G. Elenchus et mathématiques: un tournant dans le développement philosophique de Platon. In: Les paradoxes de la connaissance, essais sur le Ménon de Platon, Seleção e apresentação de M. CantoSpenber, Paris, Odile Jacob, 1991,

- The Socratic Elenchus. In: Oxford Studies in Ancient Philosophy, vol. 1, 1983, p. 27-58.

7. Witt, W. de. Epicurus and his Philosophy, University of Minnesota Press, 1954. 